\title{
ON THE ROLE OF MUSLIM INTELLECTUALS
}

\section{Murad Wilfried Hofmann}

Before delving into the subject of the role of Muslim intellectuals, we should agree on what we mean when using the term.

The meaning of the word Muslim is well-known because it has been defined in the Qur'an itself. According to Sürat al-Nisā, verse 125, a Muslim is someone "who submits his whole self to Allah, does what is good, and follows the way of Ibrahim." And according to verse 136 of the same sūrah a Muslim is he who believes "in Allah, and His messengers, and the scriptures which He has sent down to those before." Finally, Sürat al-Tawbah says in verse 71 that believing Muslims "order what is right and forbid what is wrong, observe their prayers, pay zakat, and obey Allah and His messenger."

The meaning of the word intellectual is more difficult to determine and is not defined in the Qur'an. In fact, this term has been used only since the late 19th century. For our purposes, I do not propose to define as intellectual everybody who is "cultured" or academically trained-in Arabic al-muthaqifün. Rather, I should like to restrict the term to what is called in Arabic al-mufaqirūn: analytical minds who communicate, as opinion leaders, through lecturing or publishing and do not just sit at home, thinking and criticizing.

So we know what, or who, a Muslim intellectual is. But do such individuals exist?

It is well known that the so-called elite of Europe, also of Kemalist Turkey, came to believe that there was a contradiction between being intelligent and believing in God. In fact, from the middle of the 19th century to the present time, considered it Western and Turkish academics considered it intellectually chic to be an agnostic or an atheist, in particular if one was a leftist - as if intellectualism was a privilege of the Left, and not to be found on the conservative Right.

This attitude, still pervasive today, goes back to the so-called Age of Reason and the Enlightenment-budding with Descartes in the 17th cen- 
tury, blossoming in the 18 century, and fully flowering in the 19th century. The so-called Project of Modernity (considering human reasoning as superior to any other source of insight) was originally a European emancipation movement directed against the continued domination of the minds by Christian clergy. But due to popularized thinkers and scientists like Marx, Darwin, Freud, Nietzsche, Sartre, and others, this emancipation emptied into sheer materialism and practiced (if not confessed) atheism.

Did the Age of Reason bring peace, happiness , and moral uplift to the world as promised? Quite the contrary. Man, emancipated from all religious ties and "superstitions," fought one war after the other, including two savage world wars during which millions of innocent people were killed, some even by atomic bombs.

During this supposed rule of reason, nonreligious modern man fell victim to ideologies more oppressive than religion had ever been: Nazism, Fascism, Communism, and chauvinism. Millions of people were killed in concentration camps on political or racial grounds. Man in his arrogance came close to destroying the world around him, causing devastating damage to the environment and creating diseases like AIDS and BSE.

It is curious to note that all these failures and shortcomings have not shaken Western man's belief in the superiority and rationality of his way of life, which is basically the American way of life.

It is also curious to note that the so-called elite in Western as well as in Muslim countries still act like children raised during the 19th century. They do not realize that philosophy and science have since moved away from materialism and atheism. In fact, many proud members of the totally occidentalized elite in Muslim countries are entirely unaware of the fact that intellectual giants and Nobel-prize winning scientists like Einstein, Planck, Heisenberg, Schrödinger, Eccles, and von Weizsäcker were, every one, God-believing and God-fearing.

Our proud "elite" do not even realize that modern microphysicists no longer have the problem of locating the spirit but rather the difficulty of locating the matter!

Nor do they realize that it is neither rational nor scientific to be an atheist, since the nonexistence of God has not been proven and cannot be proven. On the contrary, natural scientists and philosophers like Swinburn now conclude that, in scientific terms, it is extremely unlikely that God does not exist. ${ }^{1}$ But our so-called elite continue to act as if they had successfully banished religion from State and society. In reality they have only replaced religion by another religion, pseudoreligion, called secularism, progress, scientism or modernism.

Here, then, is the first great task of Muslim intellectuals: To challenge atheism on its own theoretical grounds, by becoming competent in phi- 
losophy and science; to prove that one can be both well educated and scientifically competent and a Muslim. Only Muslim intellectuals can see to it that it is no longer considered "chic"-but on the contrary, rather stupid-to call oneself an atheist.

This task is linked to another, rather sad situation. The Qur'an frequently appeals to man to use his reason, to observe nature, to think and reflect. Indeed, no other holy scripture does that. It is also well-known that, as a result, Muslim civilization from the 9 th to the 15 th centuries produced marvels, from Baghdad to Andalusia, from Fes to Samarkand, in all fields of knowledge. The problem is that many Muslims today nostalgically refer back to this Golden Age of Islam as if it could camouflage their misery today, and as if Islam guaranteed such superiority without adequate effort.

There are many complex reasons for the decline of the Muslim world from such heights to humiliating European colonization. But rather than staring into that past, one should turn one's attention to the fact that this Western domination continues despite decolonization. In fact, it is a feature of the postmodern world that the American way of life completely inundates the world, as if it were an obligatory model to be followed. That we are being MacDonalized is, however, not the result of a concrete policy. "Cultural imperialism" is indeed anonymous, without any conspiracy or master plan or master planner behind it. The truth is that people like Bill Gates fool around a bit, for the fun of it, and the entire world is affected, or infected, with gadgets like the Internet.

Pessimists say that technological modernization is not only inevitable (indeed undisputed) but also that it cannot be separated from westernization. Much speaks for this thesis because each technical method or product and each economic institution is the result of a mental process behind it. That means, for instance, that if you give satellite and cable TV a little finger it will take your whole hand-and you will find yourself with pornography on your screen as well.

I am nevertheless inclined to believe-and even Professor Samuel Huntington believes that now, too, after his first visit, in 1996, to Saudi Arabia - that it is possible, after all, to modernize without westernizing. This optimism is based on three powerful examples: The 'Ibadite South Algerian M'Zab region, Saudi Arabia, and Malaysia. Indeed, after decades of fantastic modernization the young generation of Saudi intellectuals seem to be more, not less, committed to orthodoxy Islam than they were 15 years ago. To keep technological innovation and westernization apart presupposes, however, a clear and firm governmental policy vis-à-vis education, a certain amount of media censorship, and strong police action against drugs of all kinds - until a Muslim society has been reestablished from the grass-roots which thanks to its living faith and its dedication to Islam is immune to the seductions of consumerism. 
At any rate, what the Muslim world is up against in its struggle with Occidental civilization is staggering. Here are a few depressing figures:

- Year after year, dozens of Nobel prizes are awarded in the sciences. No Muslim has ever been among the recipients.

- Each year in the United States alone, 55,000 books on science and technology are published.

- In the United States there are now more computers than cars, and 60 percent of them are hooked up to computer networks.

- In the Occident, there are 3,800 scientists for every million people; in the Southern regions of the world there are only 200.

Against this background, Ismail Serageldin, an Indonesian vice president of the World Bank, recently wrote:

As the world explores the marvels of genes, breaks down the secrets of the atom, reaches to the stars, and calculates the age of the oldest rocks, we Muslims ... debate whether a woman's nail polish prevents her from making full ablutions ...2

Indeed, when I read the questions frequently posed to the editors of Saudi newspapers, I have the impression that Mr. Serageldin is right. People inquire whether it is Islamic to have golden teeth or to give the Qur'an to a nonbeliever, or whether it is permitted to study Western law.

Here then is a second big task for Muslim intellectuals: to engage as Muslim political scientists and economists in the solution of contemporary questions, problems relevant today, and not to shun natural sciences. The time where $a l$-adab was favored and given more social prestige than the sciences should be a thing of the past.

But what is most relevant today for the defense of Islam and its propagation? This is the refutation of the deeply anchored suspicion that Islam is not compatible with democracy and human rights, including those of women; that Islam has no concept for a modern economy; and that Islam accepts violence for the purpose of da wa. The third big task for Muslim intellectuals is, therefore, to do their homework in these essential fields.

Al hamdu lillah, much has been done already, in particular thanks to the efforts of the International Institute of Islamic Thought (IIIT) near Washington and the International Research Institute in Islamabad. In fact, there are now major treatises written in English proving that

- based on the institutions of shürā and khilafat a Muslim State can be a multiparty democracy, a parliamentary republic, with an interestfree economy based on profit and risk sharing; ${ }^{3}$

- the status of women as practiced in many Muslim countries does not correspond to her status as given by the Qur'an, Sürat al-Nisā verse 34 notwithstanding; 
- Under no circumstances does Islam allow the use of force for $d a^{*} w a$ purposes because la ikraha fi al-din (2:256). Muhammad never permitted the use of force, not even counterforce, while in Makkah.

Surely, these are large areas of knowledge which must be explored in depth by Muslim scholars. The following points are listed only to whet the appetite for that research and to prove how much still has to be done by Muslim intellectuals:

1. If one considers that the results of shürā are binding this implies that a Muslim amir must govern by consensus. In practical terms this means government by consent of the majority, which in a mass society can only be established through elections. Is this correct?

2. Islam is compatible with laicism because it does not require that the head of State be a mullah or 'alim. Is this correct?

3. Neither the Christian nor the Muslim religion are happy with secular State, but there are no true secular States anywhere in the world today. Correct?

4. All classical human rights can be found in the Qur'an, which means that these "human rights" are divine rights, not rights conferred to man by man. Correct?

5. If Muslims throughout history had not adapted the Qur'an to their macho instincts but, on the contrary, had adapted their behavior to the Qur'an, women would not have become what can be seen in some places as second-class citizens. In particular, it has never been justified to translate al-rijāl qawwämūna 'alā al-nisā as instituting male superiority. This sentence does no more than oblige men to take care of women, with full responsibility, inasmuch as the woman needs it and her husband is capable of it. Man is not a step above her, but moves protectively a step in front of her. Is this a correct interpretation?

6. The abolishment of al-ribä can only be the last step in the conversion of an economy. There is no proof that it would not work because it has never been tried, even in Pakistan. Correct?

Where are the Muslim scholars who devote themselves to these and similar issues with knowledge, courage, and conviction?

One could call Islam a religion for intellectuals, if only because of the great role played by the Qur'an, the Hadith, and fiqh. Is it not significant that the very first verses of the Qur'an to be revealed (the first five verses of Sürat al-'Alaq) begin with the appeal to read, and speak about writing, teaching, and learning - all typical intellectual activities?

More important in this context is the fact that Islam is an entirely sober religion, free of magic and miracles - except for Revelation as such. A Muslim is not forced to believe in ideas like the Trinity, incarnation, sal- 
vation, and hereditary sin which defy logic. This is not to say that all teachings of the Qur'an are accessible to human reason. How could we understand, for instance, the relationship between predestination and free will?

The point to make is rather this: Despite the description of more than 100 asmä' al-husnah, both in the Qur'an and the Sunnah, the Islamic concept of God is so abstract that nonintellectual Muslims often run into difficulties with it. Intellectual Muslims on the other hand comprehend that Allah can only be described negatively: What $\mathrm{He}$ cannot be like (i.e., nonexistent, or one of several gods, or mortal). They are conscious that Allah escapes any definition because there is nothing with which we could compare Him: wa lam yakun lahu kufu'an ahad (112:4)! That He is both immanent-closer to man than his jugular vein-and transcendent: How could a nonphilosophical mind cope with that?

Against this background it seems quite natural that people, in the Muslim world as in the Christian, seek ways which allow them somehow to touch God. This "Baby Jesus Syndrome" is well expressed by the famous Hare Krishna song: "Oh my Lord, I really want to see you! I really want to feel you!" This basic desire explains a great deal about the devotions surrounding "Ali and Husayn in the Shi'ah world. And it is responsible for the phenomenon of devotion paid to Muslim "saints" and their graves, particularly in the Maghrib region, customs which should not exist in pristine Islam. It is indeed shocking to read in Annemarie Schimmel's most recent book, Deciphering the Signs of $\mathrm{God},{ }^{4}$ to what extent superstitions and black magic have penetrated popular Islam. Even modern Turkey is no exception; just think of the practice of $f a l,{ }^{5}$ frequently taken quite seriously, and thus being shirk.

The fourth big task for Muslim intellectuals is, therefore, to help raise the level of popular education in religion to a point where Marabouts, Babas, Dedes, Pirs, Hazretis, and Mevlanas play a lesser role. Simultaneously, Muslim intellectuals should try to raise the level of spirituality at prayer, so as to save it from routine and military drill. I am thinking of many a khutba which sounds like a general's emotional call to a fatal battle rather than an appeal to the intellectual faculties of the audience.

Of course, in some Muslim countries there has been no proper religious instruction; what was left of Muslim faith frequently passed on from grandmother to granddaughter rather than more competently from the minbar. To understand this situation does not mean that it should be tolerated.

In this connection, Muslim intellectuals have a further, fifth task to perform: to help overcome the linguistic isolation of much of the Muslim world. It may sound surprising but Islam today has two languages: 
Arabic and English. English has become the language in which more is being published on Islam than in any other language. The Muslim World Book Review in Leicester near Birmingham, U.K., publishes an index of new Islamic literature in English with some 5,000 entries each year. Much of this material should be translated into Arabic and Turkish, as is so well done already by Hasan Günes in Istanbul with his Islami Sosyal Bilimler Dergisi, a translation from the AJISS.

The same is true for translations of Arabic sources into English. Apparently, much interesting debate among Egyptian, Syrian, and Lebanese scholars is by passing European and Turkish Muslims. While it is true that, for instance, the Qur'an commentaries by Ibn Kathir, Mawdudi, and Sayed Qutb did appear in Turkish, they did so after a considerable time lag.

The battle for Islam is undoubtedly a battle for the hearts and minds of people, and such a battle cannot be won with machine guns. Where it is being fought it is being won through the media. This is the battleground where Muslim intellectuals should be at home if they are to fulfill the sixth big task. Needless to say, Muslims have a lot to learn in this domain. Radio, television, and the print media have their own laws, their own audiences, and their own unique characteristics. Radio, for instance, is more competent than TV for giving detailed information; it is being listened to by many men and women in cars who are on their way to work as well as by many men and women who are working at home or in the office.

On the whole, Muslims have been appallingly bad at selling their story, exactly because they do not believe in "selling" their message. Such qualms are, however, entirely unjustified. Reread the Qur'an to see how Allah uses forceful rhetoric to maximize the impact of His message!

Sometimes I feel that the Muslims have lost the media war already, through incompetence, inactivity, and unprofessionalism. Indeed, this field has great potential in which Muslim intellectuals may make their mark.

$D a^{w} w a$, as it is performed today, has two specific problems that only Muslim intellectuals can address. First, Muslims tend to preach to the converted. For instance, I have a feeling that the Muslim channel in Turkey is only watched by those who already are won over. TV preachers probably preach to those who already know that there is only one God, and that Muhammad is His messenger. Therefore, this audience needs to be provided with material that is useful in their actual discussions with nonbelievers. 
Second, there is a tendency to approach nonbelievers naively and in the wrong way. Somebody who is not convinced of the existence of God cannot be impressed by what God (or His messenger) said. If one has not been convinced that atheism is not an intelligent view to hold, nothing will be won through providing the person with quotations from the Qur'an. (It is circular logic to prove the existence of God by pointing out that He confirms His existence in His Qur'an.) Therefore, Muslim intellectuals must write books specifically addressed to nonbelievers, their prejudices, their belief system, and their psychology.

In this respect, today's situation is not different from the jahiliyah. As one can see from the early sūrahs revealed in Makkah, Allah put first things first. Before He moved to the elimination of alcohol, He brought home that $\mathrm{He}$, and life after death, exist.

Obviously, the task facing Muslim intellectuals is daunting. However, it should be underlined that the biggest contribution they can make is just to be there demonstrating that people who are educated and intellegent can be Muslims! In this sense, seemingly little things will turn out to have major effects. For instance, if a lonely Muslim participant in a scientific conference initiates his input with bismillahi r-rahmāni r-rahìm, he may have moved more than he can imagine.

The Muslim intellectual has not only "dos" but also "don'ts." Because of his mental flexibility and command of languages, the Muslim intellectual, like any other Muslim, is in danger of becoming too flexible and too adaptable, even apologetic, vis-à-vis the West. The result is that he becomes a "cultural Muslim," a person of Islamic background with lingering sympathy for and knowledge of Islam, but who excuses himselffrom its essentials - like prayer, fasting, or hajj-not to speak of the prohibition against alcohol. We all know such people. They take Islam with a grain of salt-which of course means they take it not at all.

The other extreme also exists: Muslim intellectuals who live and work in isolation and total opposition to the West, cultivating a sort of hijrah mentality. This, too, is undesirable, not only politically so. There must be a dialogue between Muslims and nonbelievers, between the West and Islam, between North and South, and also between Muslims who practice Islam and those who claim no more than "to have Allah in their heart."

Rejection is no solution. If we do not learn to cope with Western culture, we will be dominated by it. What is at stake is the avoidance, or not, of that very "cultural clash" predicted by Bernard Lewis and Samuel Huntington. In other words: At stake is no less than peace and the survival of Islam as a religion and as a civilization.

Thus, dialogue is of the essence. And dialogue is what intellectuals perform best. 


\section{Notes}

1. Richard Swinburn, The Existence of God (Oxford 1979).

2. In Muslim Politics Report (New York), no. 6 (March/April 1996).

3. Model contributions have recently been made in the economic field by $\mathrm{M}$. Umer Chapra and in the field of ijtihäd by Imran Ahsan Khan Nyazee, both from Pakistan, and earlier by Muhammad Asad (On State and Government in Islam).

4. Edinburgh 1994.

5. Predicting the future from coffee sediments. 